\title{
HALDANE'S RULE AND OTHER ASPECTS OF REPRODUCTIVE ISOLATION OBSERVED IN THE Anastrepha fraterculus COMPLEX (DIPTERA: TEPHRITIDAE)
}

\author{
Denise Selivon, André L.P. Perondini and João S. Morgante
}

\begin{abstract}
Some aspects of reproductive isolation between allopatric populations of two closely related species of the Anastrepha fraterculus complex ( $A$. fraterculus sp. 1 and sp. 2) were evaluated in laboratory conditions. Most of the crosses were fertile in each species as well as between sp. 2 females and sp. 1 males. In the reciprocal cross only $41.7 \%$ of the matings yielded viable progeny. Egg hatching occurred at similar rates within the two species, but was significantly lower in the crosses between the species. Adult emergence did not differ significantly among crosses. The sex ratio of adult progeny within each species, as well as in the hybrid progeny derived from sp. 1 females crossed to sp. 2 males, did not differ from the expected 1:1 ratio. However, in the crosses between sp. 2 females to sp. 1 males, a significant deviation in the sex ratio in favor of females was observed, according to the Haldane's rule. The results reinforce previous data which indicated that $A$. fraterculus sp. 1 and $A$. fraterculus sp. 2 are distinct biological entities.
\end{abstract}

\section{INTRODUCTION}

In the biological species concept of Dobzhansky (1937) and Mayr (1940), the problem of the origin of species is narrowed to the problem of the establishment of reproductive isolation mechanisms. There is an aspect of particular interest in the studies of postmating isolation which is commonly referred to as Haldane's rule. Haldane (1922) observed that "when in the F1 offspring of two different animal races (or species) one sex is absent, rare or sterile that sex is the heterozygous (heterogametic) one". As sterility or inviability of the heterogametic sex is the first step in the evolution of complete inviability or sterility, the study of Haldane's rule occurrence in incipient or related species is of particular interest to the knowledge of the speciation process.

The occurrence of cryptic species seems to be a relatively common phenomenon in the Tephritidae family (White and Elson-Harris, 1992). One of the most important agricultural pests in Brazil, the tephritid fruit fly Anastrepha fraterculus, is a species whose larvae damage a variety of commercial fruits (Malavasi et al., 1980). This species presents a wide geographic distribution which extends from southern US to northern Argentina (Norrbom and Foote, 1989; White and Elson-Harris, 1992). Based on the variability observed for different biological parameters, it was suggested that the nominal A. fraterculus comprises, in reality, a "complex of cryptic species" (Baker $e t$ al., 1944; Morgante et al., 1980; Solferini and Morgante, 1987; Steck, 1991; Steck and Sheppard, 1993; Santos and Matioli, 1995). Recently, based on extensive isozymic,

Departamento de Biologia, Instituto de Biociências, Universidade de São Paulo, Caixa Postal 11461, 05422-970 São Paulo, SP, Brasil. Send correspondence to D.S. karyotypic, and morphometric studies (Selivon, 1996), eggshell morphology (Selivon and Perondini, 1998), and unusual features of early embryogenesis (Selivon and Perondini, 1997; Selivon et al., 1997), two forms belonging to this complex were characterized, and temporarily denominated A. fraterculus sp. 1 and A. fraterculus sp. 2. Herein we report the results of crosses carried out in the laboratory between individuals of these two closely related species. It will be shown that a decrease was observed in the number of fertile crosses and in egg hatching. Additionaly, a deviation in the progeny sex ratio is described for the first time in tephritid fruit flies. This deviation is in accordance with the Haldane's rule.

\section{MATERIAL AND METHODS}

Populations of Anastrepha fraterculus sp. 1 and $A$. fraterculus sp. 2 were established in the laboratory. A. fraterculus sp. 1 derived from "feijoa" (Feijoa sellowiana) collected in Vacaria $\left(28^{\circ} 27^{\prime} \mathrm{S}, 50^{\circ} 48^{\prime} \mathrm{W}\right)$, State of Rio Grande do Sul, and A. fraterculus sp. 2 derived from guavas (Psidium guajava) collected in Conceição do Almeida $\left(12^{\circ} 30^{\prime} \mathrm{S}, 39^{\circ} 10^{\prime} \mathrm{W}\right)$, State of Bahia.

The flies were maintained in population cages ( 30 x $30 \times 60 \mathrm{~cm}$ ), fed with a diet composed of a 3:1 mixture of sugar and corn protein hydrolysate, and maintained at $25^{\circ} \mathrm{C}$ and $60 \%$ relative humidity. In the laboratory, guavas were provided for oviposition and larval development. Egg hatching was determined in individual pairs of mating of each cross type. Virgin females and males were transferred from the laboratory colonies to smaller cages $(15 \mathrm{x} 15 \mathrm{x}$ $25 \mathrm{~cm}$ ), maintained as described above. For egg collection, an artificial substrate was furnished. These were shaped like hemispheres made of $2 \%$ plain agar stained with red anilin and wrapped in Parafilm ${ }^{\circledR}$ "M" (modified from Boller, 1968), and were inspected and substituted daily. The length of time necessary for females of the con- 
trol crosses to begin oviposition, plus a week, was considered the maximum period for any female to start laying eggs. The crosses in which the females had not oviposited within this period were discarded. They were replaced and this procedure repeated until samples of 100 to 120 eggs per cross were obtained.

The analysis of the progeny sex ratio was also made in small cages, set with five pairs of mating each. The cages were maintained until a large number of pupae were obtained in each cross. The pupae were isolated and after adult emergence the number of males and females was recorded.

For statistical analysis the percent values were transformed in arcsin and the analysis done with a GraphPad InStat ${ }^{\mathrm{TM}}$ computer package.

\section{RESULTS}

Table I summarizes the results of the present study. As for the crosses, it was observed that within each species most $(83.3 \%)$ of the females produced progeny, as well as in crosses of sp. 2 females to sp. 1 males (100\%). However, in the reciprocal cross, sp. 1 female to sp. 2 male, the frequency of fertile crosses decreased to $41.7 \%$.

Table I - Results of crosses betwen Anastrepha fraterculus sp. 1 and A. fraterculus sp. 2

\begin{tabular}{|lrrrrr|}
\hline \multicolumn{3}{c}{ Crosses } & & \\
\cline { 3 - 5 } & & \multicolumn{3}{c}{ Fertile } & $\begin{array}{c}\text { \% Egg hatching } \\
\text { (mean } \pm \text { SD) }\end{array}$ \\
\cline { 3 - 5 } Females & Males & $\mathrm{N}$ & $\mathrm{N}$ & $\%$ & \\
\hline sp. 1 & sp. 1 & 6 & 5 & 83.3 & $59.1 \pm 0.05$ \\
sp. 1 & sp. 2 & 12 & 5 & 41.7 & $31.5 \pm 0.08$ \\
sp. 2 & sp. 1 & 5 & 5 & 100.0 & $32.4 \pm 0.06$ \\
sp. 2 & sp. 2 & 6 & 5 & 83.3 & $59.7 \pm 0.07$ \\
\hline
\end{tabular}

${ }^{1}$ Samples of 100 to 120 eggs per cross.
In the control, intraspecies crosses, the average frequency of egg hatching was $59.1 \%$, while this rate decrease to an average of about $30 \%$ in the crosses between the species (Table I). Since the variances were homogeneous, a single way ANOVA detected significant differences among the crosses $(\mathrm{F}=5.780$; d.f. $=3 / 19 ; \mathrm{P}=0.0071)$. Comparison by the Student-Newmann Keuls test (data not shown) indicated that: within species crosses did not differ in egg hatchability; the hybrid eggs produced by both interspecies crosses did not differ in the rate of hatching. However, the hatchability of hybrids was lower than that within species crosses.

A different result was observed, however, when the emergence of adults was analyzed. As Table II shows, the frequencies of adults emerging from a known number of pupae are similar among the different types of crosses. As for the sex ratio, no significant differences from 1:1 were observed for each species or in the cross between sp. 1 females and sp. 2 males. However, in the reciprocal cross of sp. 2 females to sp. 1 males, a significant deviation was observed, caused by a decrease in the number of males.

\section{DISCUSSION}

The results of the present analysis showed that in crosses between two closely related species of the $A$. fraterculus complex, A. fraterculus sp. 1 and A. fraterculus sp. 2, three main effects are detected. First, a reduction in the number of fertile crosses when sp. 1 females were crossed to sp. 2 males; second, a decrease in egg hatching in reciprocal crosses between the species, and third, a sex ratio deviation in favor of females in crosses of sp. 2 females to sp. 1 males.

It is not known the cause of the partial success of matings between sp. 1 females to sp. 2 males. In Anastrepha, the copulation behavior and the time of the day when matings occur seems to be very important mechanisms of prezygotic reproductive isolation (Morgante et al., 1993). Failure in mating or in the copulation process could be the cause of the increased number of unfertile crosses that was observed. Breaking down such premating barriers, even

Table II - Adult emergence and sex ratio in crosses between A. fraterculus sp. 1 and A. fraterculus sp. 2.

\begin{tabular}{|c|c|c|c|c|c|c|c|c|c|c|}
\hline \multicolumn{3}{|c|}{ Crosses } & \multicolumn{6}{|c|}{ Adult emergence } & \multirow{2}{*}{\multicolumn{2}{|c|}{$\begin{array}{c}\text { Sex ratio } \\
\text { (Yates' chi-square) }\end{array}$}} \\
\hline & & & \multicolumn{2}{|c|}{ Total } & \multicolumn{2}{|c|}{ Females } & \multicolumn{2}{|c|}{ Males } & & \\
\hline Females & Males & pupae & $\mathrm{N}$ & $\%$ & $\mathrm{~N}$ & $\%$ & $\mathrm{~N}$ & $\%$ & $\mathrm{P}$ & obs \\
\hline sp. 1 & sp. 1 & 175 & 106 & 60.6 & 54 & 50.9 & 52 & 49.1 & $0.90<\mathrm{P}<0.95$ & $\mathrm{~ns}$ \\
\hline sp. 1 & sp. 2 & 201 & 95 & 47.2 & 46 & 48.4 & 49 & 51.6 & $0.50<\mathrm{P}<0.75$ & ns \\
\hline sp. 2 & sp. 1 & 153 & 80 & 52.3 & 51 & 63.7 & 29 & 36.3 & $0.01<\mathrm{P}<0.02$ & $*$ \\
\hline sp. 2 & sp. 2 & 208 & 114 & 54.8 & 59 & 51.7 & 55 & 48.3 & $0.75<\mathrm{P}<0.90$ & ns \\
\hline
\end{tabular}

* Significant deviation at $5 \%$; ns, nonsignificant. 
in laboratory conditions, may not be a simple task. Another possibility is that copulation occurred but sperm transfer was reduced causing the female to be unfertile. These possibilities must be explored in future work.

It was also demonstrated that some degree of postzygotic isolation was found in the Anastrepha fraterculus complex. The decrease in egg hatching verified in crosses between sp. 1 and sp. 2 individuals was actually expected since they differ considerably in several biological characteristics (Selivon, 1996). It was not possible to conclusively determine the reason for this decrease. Besides possible problems in the development of the hybrid eggs due to failure of genome adjustment, the decrease in egg hatching may also be related to cytoplasmic incompatibility. Selivon et al. (1996) reported that eggs of A. fraterculus (now recognized as sp. 2) harbor a large population of symbiontic bacteria, which seems to be present also in the eggs of A. fraterculus sp. 1 (Selivon, D., uniplublished results). Cytoplasmic incompatibility caused by bacteria, mainly of genus Wolbachia, was found in several other insect species (Stevens and Wade, 1990; Rousset et al., 1992; Werren et al., 1995a,b). The bacteria can alter the reproductive biology of their hosts in several ways, like uni or bidirectional incompatibility, sex ratio biases, parthenogenesis and host fecundity (reviews in Werren and Guo, 1995a; Johanowicz and Hoy, 1998). Wolbachia-like organisms may also cause reproductive isolation of different geographical strains of Drosophila species (Boyle et al., 1993), and may be one mechanism involved in speciation processes (Werren, 1997; Giordano et al., 1997).

The sex ratio deviation found in progenies of sp. 2 females crossed to sp. 1 males from the different populations is in line with the Haldane's rule since, in these cases, a reduction in number of males was observed. The explanation for this empirical rule is controversial, but the presence of this kind of deviation reflects the existence of postmating isolation mechanisms (Coyne and Orr, 1989a; Coyne, 1992; Wu and Palopoli, 1994). Wherever lies the explanation for Haldane's rule, a fundamental question remains: is postmating isolation really an important cause of speciation? As considered by Coyne and Orr (1989a), if complete mating discrimination between species always evolves before substantial hybrid sterility or inviability, then postmating isolation would be irrelevant to speciation. They found, however, that among geographically isolated species, the restriction of gene flow due to assortative mating evolves at approximately the same rate as the restriction of gene flow due to postmating isolation. Hence, hybrid sterility and inviability must therefore be considered as major contributors to reproductive isolation during allopatric speciation. The acquisition of ethological isolation in the absence of postmating isolation is known in only a case in Drosophila (Wu et al., 1995).

On the other hand, Coyne and Orr (1989b) demonstrated that Haldane's rule often results from a pattern of speciation in which males, from both reciprocal crosses between two taxa, became sterile or inviable before any effect arises in the females. In addition, there are very few cases in which both male and female offspring of the two reciprocal crosses are sterile or inviable early in the process of speciation. This means that total sterility or inviability of hybrid progeny is nearly always preceded by sterility or inviability of males alone. Haldane's rule, therefore, represents a nearly obligatory first step in the evolution of postmating isolation in Drosophila (Coyne and Orr, 1989b). The observation of Haldane's rule in crosses of sp. 2 females to sp. 1 males would, at first, suggest that these two forms are closely related presenting slightly genetic differences. However, the absence of sex ratio deviation in the reciprocal crosses which nonetheless present a lower egg hatchability indicates that in these cases, both sexes are being affected. Hence, according to the hypothesis of Coyne and Orr (1989b), the data so far obtained in Anastrepha fraterculus would suggest that sp. 1 and sp. 2, although may not be completely isolated, present a degree of genetic distinction which is beyond the initial stages of speciation.

\section{ACKNOWLEDGMENTS}

Funding provided by FAPESP, CNPq and FINEP. A.L.P.P. is a research fellow of CNPq. Publication supported by FAPESP.

\section{RESUMO}

Neste trabalho foram avaliados alguns aspectos do isolamento reprodutivo entre populações alopátricas de duas espécies do complexo Anastrepha fraterculus (A. fraterculus sp. 1 e sp. 2) em condições de laboratório. A maioria dos cruzamentos intraespecíficos, assim como aqueles entre fêmeas da sp. 2 e machos de sp. 1, foram férteis. No cruzamento recíproco, somente $41.7 \%$ resultaram em progênies viáveis. A taxa de eclosão das larvas foi similar para as duas espécies, mas significativamente menor para os cruzamentos interespecíficos. A proporção sexual da progênie adulta foi de 1:1 tanto nos cruzamentos intraespecíficos quanto naqueles de fêmeas de sp. 1 com machos de sp. 2. Entretanto, nos cruzamentos entre fêmeas de sp. 2 com machos de sp. 1 houve um desvio significativo na proporção sexual das progênies, com um excesso de fêmeas. Esta observação está de acordo com a regra de Haldane, cuja ocorrência reflete a existência de isolamento reprodutivo pós-zigótico. Os resultados reforçam a sugestão da existência de dois taxa distintos em A. fraterculus.

\section{REFERENCES}

Baker, A.C., Stone, W.E., Plummer, C.C. and MacPhail, H. (1944). A review of studies on the Mexican fruit fly and related Mexican species. United States Dept. Agric. Miscellaneous Publication 531: 1155.

Boller, E.F. (1968). An artificial oviposition device for the European cherry fly, Rhagoletis cerasi. J. Econ. Entomol. 61: 1227-1234.

Boyle, L., O'Neil, S.L., Robertson, H.M. and Karr, T.L. (1993). Interspecific and intraspecific horizontal transfer of Wolbachia in Drosophila. Science 260: 1796-1799. 
Coyne, J.A. (1992). Genetics and speciation. Nature 355: 511-515.

Coyne, J.A and Orr, H.A. (1989a). Two rules of speciation. In: Speciation and its Consequences (Otte, D. and Endler, J., eds.). Sinauer, Sunderland, MA, pp. 180-207.

Coyne, J.A. and Orr, H.A. (1989b). Patterns of speciation in Drosophila. Evolution 43: 362-381.

Dobzhansky, Th. (1937). Genetics and the Origins of Species. Columbia Univ. Press, New York.

Giordano, R., Jackson, J.J. and Robertson, H.M. (1997). The role of Wolbachia bacteria in reproductive incompatibilities and hybrid zones of Diabrotica beetles and Grillus crickets. Proc. Natl. Acad. Sci. USA 94: 11439-11444.

Johanowicz, D. and Hoy, M.A. (1998). The manipulation of arthropod reproduction by Wolbachia endosymbionts. Florida Entomol. 81: 310-317.

Haldane, J.B.S. (1922). Sex ratio and unisexual sterility in animal hybrids. J. Genet. 12: 101-109.

Mayr, E. (1940). Speciation phenomena in birds. Am. Nat. 74: 249-278.

Malavasi, A., Morgante, J.S. and Zucchi, R.A. (1980). Biologia de "moscas-das-frutas". I. Lista de hospedeiros e ocorrência. Rev. Bras. Biol. 40: 9-16.

Morgante, J.S., Malavasi, A. and Bush, G.L. (1980). Biochemical systematics and evolutionary relationships of neotropical Anastrepha. Ann. Entomol. Soc. Am. 73: 622-630.

Morgante, J.S., Selivon, D., Solferini, V.N. and Matioli, S.R. (1993). Evolutionary patterns in specialist and generalist species of Anastrepha. In: Fruit Flies: Biology and Management (Aluja, M. and Liedo, P., eds.). Springer-Verlag, New York, pp. 15-20.

Norrbom, A. and Foote, R.H. (1989). The taxonomy and zoogeography of the genus Anastrepha (Diptera: Tephritidae). In: Fruit Flies: Their Biology, Natural Enemies and Control. World Crop Pests, 3(A) (Robinson, A.S. and Hooper, G., eds.). Elsevier, Amsterdam, pp. 1526.

Rousset, F., Bouchon, D., Pintureau, B., Juchault, P. and Solignac, M. (1992). Wolbachia endosymbionts responsible for various alterations of sexuality in arthropods. Proc. R. Soc. Lond. B 250: 91-98.

Santos, P. and Matioli, S.R. (1995). Padrões de variabilidade contrastantes para mtDNA e rDNA em Anastrepha. Rev. Bras. Genet. 18 (Suppl.): 276 (Abstract)

Selivon, D. (1996). Estudo sobre a diferenciação populacional em Anastrepha fraterculus (Wiedemann) (Diptera: Tephritidae). Doctoral thesis, Departamento de Biologia, Instituto de Biociências, USP, São Paulo.

Selivon, D. and Perondini, A.L.P. (1997). Extrusion of yolk masses by hybrid embryos of two cryptic species of Anastrepha fraterculus (Diptera: Tephritidae). Braz. J. Genet. 20: 253-256.

Selivon, D. and Perondini, A.L.P. (1998). Eggshell morphology in two cryptic species of the Anastrepha fraterculus complex (Diptera: Tephritidae). Ann. Entomol. Soc. Am. 91: 473-478.

Selivon, D., Morgante, J.S., Ribeiro, A.F. and Perondini, A.L.P. (1996). Extrusion of masses of yolk during embrionary development of the fruit fly Anastrepha fraterculus. Invert. Reprod. Develop. 29: 1-7.

Selivon, D., Morgante, J.S. and Perondini, A.L.P. (1997). Egg size, yolk mass extrusion and hatching behavior in two cryptic species of Anastrepha fraterculus (Wiedemann) (Diptera: Tephritidae). Braz. J. Genet. 20: 587-594.

Solferini, V.N. and Morgante, J.S. (1987). Karyotype study of eight species of Anastrepha (Diptera: Tephritidae). Caryologia 40: 229-241.

Steck, G. (1991). Biochemical systematics and population genetic structure of Anastrepha fraterculus and related species (Diptera: Tephritidae). Ann. Entomol. Soc. Am. 84: 10-28.

Steck, G.J. and Sheppard, W.S. (1993). Mitochondrial DNA variation in Anastrepha fraterculus. In: Fruit Flies: Biology and Management (Aluja, M. and Liedo, P., eds.). Springer-Verlag, New York, pp. 9-14.

Stevens, L. and Wade, M.J. (1990). Cytoplasmically inherited reproductive incompatibility in Tribolium flour beetles: the rate of spread and effect on population size. Genetics 124: 367-372.

Werren, J.H. (1997). Biology of Wolbachia. Annu. Rev. Entomol. 42: $587-$ 609.

Werren, J.H. and Guo, L.R. (1995a). Evolution and phylogeny of Wolbachia: reproductive parasites of arthropods. Proc. R. Soc. Lond. B 261: 55-71.

Werren, J.H., Guo, L.R. and Windsor, D.W. (1995b). Distribution of Wolbachia in neotropical arthropods. Proc. R. Soc. Lond. B 262: 147204.

White, I.M. and Elson-Harris, M.M. (1992). Fruit Flies of Economical Significance; Their Identification and Bionomics. CAB International, Wallingford, UK.

Wu, C.-I. and Palopoli, M.F. (1994). Genetics of postmating reproductive isolation in animals. Ann. Rev. Genet. 27: 283-308.

Wu, C.-I., Hollocher, H., Begun, D.J., Aquadro, C.F., Xu, Y. and Wu, M.-L. (1995). Sexual isolation in Drosophila melanogaster: a possible case of incipient speciation. Proc. Natl. Acad. Sci. USA 92: 2519-2523.

(Received October 26, 1999) 